\title{
O MAGISTÉRIO CATÓLICO E A DEFESA DA VIDA HUMANA NA SUA ORIGEM, À LUZ DO DADO CIENTÍFICO
}

\author{
Prof. Adriano Corrêa da Silva, sjs"
}

\section{RESUMO}

O legado missionário da Igreja Católica de defesa da vida humana, em todas as etapas, sobretudo na sua origem, uma vez que vivemos numa época de intensos ataques à vida nascente, sempre foi uma constante ao longo da história, mesmo quando não existia uma unanimidade no Sagrado Magistério quanto ao momento exato da infusão da alma. Veremos que os dados, que hoje a embriologia fornece, justificam ainda mais tal defesa.

Palavras-chave: Defesa da vida nascente. Infusão da alma espiritual. Embriologia.

\begin{abstract}
The legacy of the Catholic Church's mission to defend human life in every stages, particularly in its origin, since we live in a time of intense attacks on unborn life, has always been a constant throughout history, even when there was no unanimity in the Sacred Magisterial regarding the exact timing of the infusion of the soul. We will see that data, which today embryology provides that justify still more this defense.
\end{abstract}

Keywords: Defense of unborn life. Infusion of the spiritual soul. Embryology.

Padre Adriano Corrêa da Silva, sjs, é religioso da Fraternidade Jesus Salvador, na Diocese de Santo Amaro. Mestrando em Teologia Moral na área de Bioética pela Pontifícia Universidade Católica de São Paulo - Campus Ipiranga. Leciona moral social no Instituto São Boaventura da citada diocese e auxilia na Igreja da Catedral da Sé. 


\section{INTRODUÇÃO}

O objetivo deste artigo é mostrar o amadurecimento da Igreja Católica ao longo da história sobre o momento em que a alma espiritual é infusa, permitindo, deste modo, o surgimento da pessoa humana. E para isso, tal estudo perpassa por renomados teólogos católicos que fazem uma distinção entre o sexo masculino e o feminino, quanto ao momento da infusão da alma.

Porém, apesar destas discrepâncias, quanto ao momento exato da animação, discussão interna à teologia, tal estudo nos possibilitará perceber que a posição diacrônica da Igreja Católica sempre foi de estar ao lado da vida nascente, defendendo-a em todas as circunstâncias, inclusive, aplicando sanções canônicas para a prática do aborto.

A Igreja arrefece ainda mais suas forças se colocando na direção da vida e contra o aborto, quando se apoia em dados científicos sobre o embrião humano de que a vida já existe a partir dos primeiros instantes da concepção.

\section{ORIGEM DA VIDA HUMANA}

Em qualquer discussão que podemos fazer em torno do debate sobre a vida nascente, existe sempre uma pergunta fundamental e responsável que ilumina a reflexão sobre a eticidade da interrupção da gestação: "Quando começa a vida humana no desenvolvimento embrionário ou a partir de que momento existe um ser humano ou uma vida humana?"

O Sagrado Magistério da Igreja Católica considera, como sendo mais seguro, que a vida humana tenha o seu início desde a fecundação, quando aparece um genótipo, caracterizado pelos 46 cromossomos, distinto do pai e da mãe, ainda que possa desdobrar-se em vários gêmeos, em vários dias.

A partir do momento em que o óvulo é fecundado, inaugura-se uma nova vida que não é aquela do pai ou da mãe, e sim, de um novo ser humano que se desenvolve por si mesmo. Jamais chegará a ser humano se já não o é desde então. A esta evidência de sempre a genética moderna fornece uma preciosa confirmação [...]. Com a

1 FERNÁNDEZ, Javier Gafo. 10 palavras-chaves em bioética, p. 47. 
fecundação tem início a aventura de uma vida humana, cujas principais capacidades exigem um tempo para desenvolver-se e poder agir. ${ }^{2}$

Para a genética, o primeiro dado incontestável é que, no momento da fertilização, em que acontece a fusão de duas células, o oócito ${ }^{3}$ e o espermatozoide, dá-se a formação de uma nova entidade biológica, ou seja, um novo genoma, que, já traz em si mesma uma nova vida individual. Por meio deste processo de fertilização, as duas células, que constituem dois sistemas independentes, mas ordenados um para o outro, dá origem a um novo sistema que começa a operar como uma unidade. Deste modo, já não são dois sistemas que estão agindo independentemente um do outro, mas um único sistema, chamado zigoto ou embrião unicelular.

Este novo genoma, responsável por identificar o embrião unicelular como biologicamente humano e especificar sua individualidade, não está numa posição de inércia no sentido de ser executado por órgãos fisiológicos da mãe, adquirindo um esquema de passividade, mas é um novo projeto que se constrói a si mesmo, assumindo o papel de ator principal de si.

A partir do momento em que o óvulo é fecundado imediatamente os dois subsistemas - os gametas, masculino e feminino - se integram, iniciando um novo sistema, que tem duas características fundamentais: primeira, o novo sistema "começa a operar como uma nova unidade, intrinsecamente determinada a atingir sua forma específica terminal, se for postas todas as condições necessárias. Daí a clássica e ainda corrente terminologia de embrião unicelular". ${ }^{4}$ A segunda característica, "é que o centro biológico ou estrutura coordenadora dessa nova unidade é o genoma de que está dotado o embrião unicelular [...]. É esse genoma que identifica o embrião unicelular como biologicamente humano e especifica sua individualidade". ${ }^{5}$

Vejamos os quatro pontos essenciais desta análise, que a própria ciência genética nos oferece.

2 Sagrada Congregação para a Doutrina da Fé. Documentos publicados desde o Concílio Vaticano II até nossos dias (1965-2010). Declaração sobre o aborto provocado III, n. 12-13.

3 COUTINHO, A. Céu (org.). Dicionário Enciclopédico de Medicina, p. 1646: sinônimo de ovócito. Célula derivada da oogónia (célula primordial do ovário do feto, que se transforma no oócito) e que constitui uma das fases da evolução do óvulo.

4 SGRECCIA, Elio. Manual de Bioética - I: fundamentos e ética biomética, p. 343.

5 Ibidem. 
O primeiro apontamento refere-se ao zigoto: "o encontro de duas células especializadas, chamadas gametas, uma de origem materna (óvulo) e outra de origem paterna (espermatozoide)"7 que, sofrendo o processo de singamia, ou seja, de fusão das duas células, dá origem a uma nova célula - o zigoto - origem de uma nova vida humana.

Este embrião unicelular inicia uma atividade, como um novo sistema, como um ser vivente ontologicamente uno. $E$ entre as muitas atividades coordenadas desta nova célula, durante um período de cerca de 20 a 25 horas, podemos citar as mais importantes:

1) a organização do novo genoma, que representa o principal centro informativo e coordenador para o desenvolvimento do ser humano e de todas as suas ulteriores atividades;

2) o início do primeiro processo mitótico, que leva o embrião a duas células. $^{8}$

Ainda falando sobre o zigoto, deve-se sublinhar dois aspectos principais: primeiramente, não é um ser anônimo, pois tem sua identidade determinada; e em segundo, esta nova célula é intrinsecamente orientada a um bem definido, formar um sujeito humano, com uma precisa forma corpórea, de modo que, tanto a identidade como a orientação, são essencialmente dependentes do genoma, que leva, em si, toda a informação genética do novo indivíduo. É exatamente esta informação, substancialmente invariável, que porta o embrião, que estabelece sua pertença à espécie humana.

As ciências biológicas nos fornecem dados que nos permitem afirmar: o zigoto é o ponto exato no qual um indivíduo humano inicia seu próprio ciclo vital.

O segundo ponto desta análise vai do zigoto ao blastocisto - a primeira etapa do desenvolvimento do zigoto:

Durante um período de mais ou menos cinco dias acontece uma rápida multiplicação celular, sob o controle de um grande número de

6 COUTINHO, A. Céu (org.). Dicionário Enciclopédico de Medicina, p. 2473: [gr. zygotós atrelado] - célula resultante da união dos dois gametas masculino e feminino, o ovo fertilizado.

7 VIDAL, Marciano. Ética teológica: conceitos fundamentais, p. 402.

8 Pontifício Conselho para a Família. Lexicon: termos ambíguos e discutidos sobre família, vida e questões éticas, p. 192. 
genes implicados nos muitos eventos do ciclo mitótico e na produção de proteínas necessárias para a estrutura e as funções do crescente número de células. ${ }^{9}$

E dentro desse primeiro estágio de desenvolvimento do embrião está o novo genoma, já constituído no zigoto, quem assume o controle tornando-se a base e o suporte da unidade estrutural e funcional do mesmo.

O terceiro ponto essencial desta análise segue-se do blastocisto ao disco embrionário - é a segunda etapa do desenvolvimento do embrião. É o estágio em que ocorre a expansão dos blastocistos e seu implante no útero, durante o qual mãe e embrião fazem de tudo para estabelecer uma harmonia. $^{10}$

O quarto apontamento da análise é a fase chamada de fetal, levando em consideração o plano geral do corpo, onde corre a modelagem dos diferentes órgãos e tecidos:

Na quinta semana de gestação, no embrião, com cerca de $1 \mathrm{~cm}$ de comprimento, já se esboça o cérebro primitivo, coração, pulmões, os tratos gastroentérico e genitourinário; na sexta semana já são claramente visíveis os esboços dos membros e, ao fim da sétima semana, a forma corpórea está completa. ${ }^{11}$

Estas afirmações científicas sobre o embrião humano levou a compilação de um documento pelo Centro de bioética da Universidade Católica, "Identidade e Estatuto do embrião humano", em que a Igreja se serve para defender a vida humana já na sua fase embrionária.

De acordo com o grande embriologista C. H. Waddington, responsável em fazer um aprofundamento do processo biológico, em que ele a definiu de "epigênese" ou "a contínua emergência de uma forma de etapas precedentes", e ainda, de acordo com o documento supracitado da Universidade Católica sobre o estatuto do embrião humano, esse processo de desenvolvimento tem três propriedades biológicas: a coordenação, a continuação e a graduação. ${ }^{12}$

\footnotetext{
Ibidem, p. 193.

o Ibidem, p. 194.

1 Ibidem, p. 194.

12 Ibidem, p. 195.
} 
A primeira propriedade é a coordenação: "Em todo o processo da formação a partir do zigoto, há uma sucessão de atividades moleculares e celulares sob a guia da informação contida no genoma". ${ }^{13}$ A presença do genoma no embrião humano, garantindo e exigindo uma rigorosa unidade do ser em desenvolvimento, nos leva a uma conclusão que tal embrião, mesmo nos primeiros catorze dias, não pode ser tratado como um acúmulo de células, visto que já é um indivíduo real a cada etapa num processo dinâmico e autônomo, criando o seu próprio espaço como organismo.

O zigoto, a célula fundada, já tem em si todo o ser humano adulto programado. Ele não tem cérebro, não pode pensar ou ter ideias. Mas pode criar um cérebro, seguindo leis e normas que estão no código vivo que é essa celulazinha menor que a cabeça de um alfinete. ${ }^{14}$

A segunda propriedade é a continuidade: “O zigoto é o primórdio do novo organismo, que está no verdadeiro início do seu próprio ciclo vital. Se considerarmos o perfil dinâmico desde ciclo no tempo, aparece claramente que isso procede sem interrupções" ${ }^{15}$ Neste processo de desenvolvimento não há nenhuma etapa mis importante que outra; todas elas são parte de um processo contínuo, de modo que, se cada etapa não se realiza normalmente, no tempo e numa sequência, o desenvolvimento seguinte não será possível.

A terceira e a mais importante propriedade é a graduação:"16 "É uma lei intrínseca do processo de formação de um organismo pluricelular o fato de ele adquirir a sua forma final através da passagem de formas mais simples a formas cada vez mais complexas".17 É justamente a existência dessa lei da gradualidade que manterá permanentemente a identidade e a individualidade do embrião humano, através de todo o processo de desenvolvimento.

É precisamente por causa desta lei epigenética intrínseca, que está inscrita no genoma e começa a atuar desde o momento da fusão dos dois gametas, que cada embrião e, portanto, também o embrião humano, mantém permanentemente a própria identidade, individualidade e unicidade, permanecendo sem interrupção o mesmo indivíduo idêntico

\footnotetext{
SGRECCIA, Elio. Manual de Bioética - I: fundamentos e ética biomética, p. 344.

JOSAPHAT, Carlos. Ética mundial: esperança da humanidade globalizada, p. 397.

Pontifício Conselho para a Família, Lexicon, p. 195.

Ibidem, p. 196.

SGRECCIA, Elio, Manual de Bioética, op. cit., p. 344.
} 
durante todo o processo de desenvolvimento, desde a singamia em diante, apesar da sempre crescente complexidade de sua totalidade. ${ }^{18}$

Em síntese, apoiados nesses dados científicos, se pode dizer:

A rapidez do desenvolvimento e da organização é tal que no final da $8^{a}$ semana [...] a organização está terminada e o embrião possui, ainda que em miniatura, todas as estruturas características do homem, com um sexo bem definido, como são reconhecidos no final da gravidez. ${ }^{19}$

No final da oitava semana, o embrião possui todas as características do homem, com um sexo definido, como são reconhecidas no final da gravidez.

Esses dados científicos sobre o embrião humano trouxeram, para a Igreja, uma confirmação sobre a sua missão de defesa da vida já a partir dos primeiros instantes da concepção. Portanto, a Igreja, arrefece ainda mais suas forças se colocando na direção da vida e contra o aborto. Porém, veremos a seguir que nem sempre o Sagrado Magistério foi unânime acerca do momento exata da infusão da alma.

Sim! Pois tu formaste os meus rins, tu me teceste no seio materno. Eu te celebro por tanto prodígio, e me maravilho com as tuas maravilhas! Conhecias até o fundo do meu ser. Teus olhos viam o meu embrião (SI 139,13-14.16a).

\section{INFUSÃO DA ALMA ESPIRITUAL}

Não é de se estranhar que o Magistério da Igreja Católica, durante muito tempo, foi marcado por uma discrepância quanto ao momento da infusão da alma. Os Padres da Igreja dividiram-se em duas correntes de opinião: os que defendiam a animação imediata, desde o momento da fecundação e os que eram partidários da animação mediata ou retardada, isto é, depois de certo tempo.

Os primeiros explicavam a origem da alma humana por uma préexistência anterior a sua união com o corpo (platonismo cristão) ou por uma derivação da alma dos pais (traducianismo), eram partidários

18 FUENTES, R. P. Miguel Ángel. As verdades roubadas, p. 173-174.

19 Ibidem, p. 345. 
da animação imediata. Em troca, os segundos, que seguiam a tese de que as almas são criadas por Deus (criacionismo), apoiavam a opinião da animação retardada. ${ }^{20}$

Santo Agostinho no século V, dizia que somente depois de 40 dias após a fecundação é que se podia falar em pessoa humana, ou seja, que correspondesse a uma unidade de corpo e alma ou, ainda, hominização. Isso no caso do feto masculino. Ao passo que, para o feto feminino, exigia-se o dobro, ou seja, 80 dias para se considerar uma pessoa. ${ }^{21}$

A tese criacionista foi a que se impôs e a que passou a ser aceita pela Igreja, de tal maneira que podemos verificar o Papa Pio XII afirmando: "a fé católica obriga-nos a sustentar que as almas são criadas imediatamente por Deus". ${ }^{22}$

A questão da animação mediata ou sucessiva foi introduzida por alguns Padres da Igreja para combater o assim chamado traducianismo teorizado por Tertuliano: este, para explicar a transmissão do pecado original, supunha que não apenas o corpo, mas também a alma fosse transmitida pelos pais; para afastar essa tese teológica, outros Padres e depois S. Tomás de Aquino propuseram a teoria da animação sucessiva. $^{23}$

A teoria da animação sucessiva consistia em afirmar que a sua origem era diferente da origem do corpo, mesmo estando em uma união substancial com ele. A alma é criada imediatamente por Deus. Santo Tomás de Aquino ainda supunha certa organização do corpo para a infusão da alma. Sendo, portanto, a alma a forma do corpo.

Como se pode ver, Santo Tomás de Aquino, no século XIII, também se utilizou da mesma posição assumida anteriormente por Santo Agostinho, quando então a partir de 40 dias pudesse reconhecer como humano o embrião, com a infusão da alma racional. ${ }^{24}$

20 VIDAL, Marciano. Moral cristã em tempos de relativismos e fundamentalismos, p. 89.

21 BARCHIFONTAINE, Christian de Paul de. Bioética e início da vida: alguns desafios, p. 111.

22 Ibidem.

23 SGRECCIA, Elio, Manual de Bioética, op. cit., p. 357.

24 BARCHIFONTAINE, Christian de Paul de, op. cit., p. 111. 
Tal doutrina foi assumida oficialmente pela Igreja Católica a partir do Concílio de Trento encerrado em 1563, de modo que era partindo de tal consideração que a Igreja avaliava ética e canonicamente as ações abortivas. ${ }^{25}$ Porém, esta teoria sempre foi contestada por outros teólogos que, buscando embasamento na autoridade de Tertuliano, século III, e de Santo Alberto Magno, século XIII, defendiam a hominização imediata, ou seja, desde a fecundação já tratar de um ser humano em processo. ${ }^{26}$

Como podemos constatar, "na Idade Média há a coexistência das duas teorias, isto é, a animação imediata e a sucessiva". ${ }^{27}$

O Magistério da Igreja não interveio decisoriamente na disputa; condenou somente as duas proposições extremas: que a alma se infunde no momento do nascimento (Inocêncio XI, em 1679) e que a infusão da alma tem lugar no primeiro ato da inteligência da criança (Leão XIII, em 1887 contra Rosmini)..$^{28}$

No século XVIII, Santo Afonso Maria de Ligório, falecido em 1787, admitia o aborto terapêutico, caso corresse risco imediato à vida da mãe.

Contudo, essa discussão sobre o feto "inanimado" - que ainda não teria alma - teve por encerrada oficialmente com a divulgação da "Apostolica Sedia" em 1869, quando o Papa Pio IX condenou toda e qualquer interrupção voluntária da gravidez.

Neste mesmo século XIX, discutia-se sobre o aborto direto e indireto.

E Roma passou a admitir o aborto indireto, em caso de gravidez tubária ou de câncer no útero. Matar diretamente o feto é sempre proibido. A extirpação de um câncer do útero ou a preservação da vida da mãe exige, por vezes, medidas que não matam diretamente o embrião, mas

25 SGRECCIA, Elio, op. cit., p. 357: "O aborto era um pecado, um crime até, em qualquer momento que fosse cometido; a dúvida, se houvesse, recaía sobre a qualificação do crime, ou seja, se deveria ser definido como homicídio ou simplesmente como delito específico contra a vida, e a essa questão estava ligada uma diferença de penas canônicas, mas não o juízo sobre a ilicitude".

26 CAMARGO, Marculino, Ética, vida e saúde, p. 17.

27 Ibidem.

28 VIDAL, Marciano, op. cit., p. 90. 
têm por consequência 'indireta', porque não queria por si a expulsão do mesmo, não viável. ${ }^{29}$

Enquadra-se perfeitamente neste caso o conceito ético do duplo efeito, ${ }^{30}$ que, por ato voluntário de conservação da vida da mãe pode resultar, consequentemente, um ato involuntário de interrupção da vida do feto.

A defesa da vida humana, no seu início, assumida pela Igreja, como um princípio de sua missão, foi adquirindo um amadurecimento ainda maior com as novas descobertas da biologia, de modo especial da embriologia, o que nos leva a pensar que: se os cientistas, filósofos e teólogos, que sustentaram a teoria da animação retardada, conhecessem as atuais descobertas científicas na área da biogenética, não teriam sustentado tal teoria. ${ }^{31}$

E mesmo havendo esta disparidade, quanto ao momento em que acontece a infusão da alma, teoria da animação imediata e teoria da animação retardada ou sucessiva, a Igreja sempre foi a favor da vida humana em qualquer de sua etapa, tomando posição veementemente contra o aborto. ${ }^{32}$

Ao longo da história, os Padres da Igreja, bem como os seus Pastores e os seus Doutores, ensinaram a mesma doutrina contra o aborto, partindo do seguinte princípio: "vida provável, vida certa", ${ }^{33}$ "sem que as diferentes opiniões acerca do momento da infusão da alma espiritual tenham introduzido uma dúvida sobre a ilegitimidade do aborto". ${ }^{34}$

29 BARCHIFONTAINE, Christian De Paul De. Bioética e início da vida: alguns desafios, $\mathrm{p}$. 111.

30 CIPRIANI, Giovanni. O embrião humano: na fecundação, o marco da vida, p. 96-97: "O princípio moral que deve orientar o médico, nesse caso, é o 'princípio do duplo efeito', ou seja, sabemos que os atos humanos não só produzem efeitos bons, mas também, em alguma situação, efeitos maus - não desejados intencionalmente - com os bons. É este o caso. O médico para salvar a vida da mãe (efeito bom), pode causar a morte do feto (efeito mau). Na ética, o agir segundo o 'princípio do duplo efeito' é permitido quando: a ação não é intrinsecamente má nem moralmente má em si mesma; o efeito mau não é intencional em si mesmo; o efeito mau não é meio para obter o efeito bom; há uma razão proporcionada para causar o efeito mau".

31 FUENTES, Miguel Ángel. As verdades roubadas, op., cit., p. 169.

32 Ibidem, p. 168.

33 Ibidem, p. 169.

34 Sagrada Congregação para a Doutrina da Fé. Documentos publicados desde o Concílio Vaticano II até nossos dias (1965-2010). Declaração sobre o aborto provocado II, n. 7. 
A posição do magistério da Igreja, sobre o momento em que começa a existir o ser humano e quando se dá a infusão da alma, não é outra senão o momento da fecundação, visto que a partir deste momento se dão nesse novo ser, três propriedades fundamentais - coordenação, continuação e graduação - sinalizando que temos um indivíduo autônomo, mesmo que ainda não tenha desenvolvido todas as suas virtualidades, justificando, deste modo, a origem da vida humana já no instante da fecundação à luz do dado científico:

É certo que nenhum dado experimental, por si só, pode ser suficiente para reconhecer uma alma espiritual: todavia, os conhecimentos científicos acerca do embrião humano fornecem uma indicação valiosa para discernir racionalmente uma presença pessoal desde esta primeira aparição de uma vida humana. ${ }^{35}$

Do ponto de vista da ética, faz-se necessário levar em consideração os pressupostos ontológicos e antropológicos sobre o valor da vida humana. Numa perspectiva clássica ou tradicional da ética, podemos afirmar que o ser humano não é meramente um ser da natureza, mas um ser composto de corpo e princípio vital ou alma que, sendo espiritual, tem destinação transcendente, ou seja, capacidade de abertura para Deus e para os outros. Portanto, a vida é um dom sagrado que, por consequência, deve ser inviolável. ${ }^{36}$ Esta é a base sobre a qual está assentada a ética tradicional no ocidente.

Todavia, a partir dos anos 1970, surge um novo momento histórico de discussões em torno da questão sobre o aborto, em vista dos problemas de malformações ${ }^{37}$ decorrentes de drogas, como é o caso da talidomida, ${ }^{38}$ instaurando um novo modo de avaliar as coisas.

Mesmo diante de uma situação de malformação fetal, seja qual for a sua origem, "o homem é chamado a viver a mesma entrega ao Senhor e a renovar

35 Sagrada Congregação para a Doutrina da Fé. Donum Vitae I, n. 1.

36 NEDEL, José. Ética aplicada: pontos e contrapontos, p. 31.

37 COUTINHO, A. Céu (org.). Dicionário Enciclopédico de Medicina, p. 646: [lat. deformatio, deformitas] alteração da forma de um órgão ou de parte de um órgão adquirida como consequência de uma doença, de um traumatismo, de uma posição viciosa etc. $O$ uso consagrou malformação como a alteração congênita; p. 1420: Alteração congênita da forma de um órgão.

38 Ibidem, p. 2175: Medicamento sedativo e hipnótico. Retirada do mercado, em conseqüência de se ter verificado que, quando administrado a mulheres grávidas, provoca malformações no feto. 
a sua confiança fundamental naquele que cura todas as enfermidades". ${ }^{39}$ A família deste novo ser, especialmente a mãe, é chamada a abandonar-se totalmente à vontade do Altíssimo, ao seu desígnio de amor, mesmo quando toda esperança de saúde parece não ser possível para o feto que está sendo gestado, em seu ventre materno.

O crente está animado pela fé inabalável no poder vivificador de Deus. A doença não o leva ao desespero nem ao desejo da morte, mas a uma invocação cheia de esperança. Confiei mesmo quando disse: "Sou um homem de todo infeliz". ${ }^{40}$

Por isso, a sua opção é sempre em favor e defesa da vida humana, visto que ele não é senhor nem da vida nem da morte, mas o seu administrador e tutor. O ser humano é ministro do desígnio de Deus. ${ }^{41}$

Assim, afirma o Sagrado Magistério:

Desde o momento da concepção, a vida de todo ser humano deve ser respeitada de modo absoluto, porque o homem é, na terra, a única criatura que Deus quis por si mesma, e a alma espiritual de cada um dos homens é imediatamente criada por Deus; todo o seu ser traz a imagem do Criador. A vida humana é sagrada porque desde o seu início comporta a ação criadora de Deus e permanece para sempre em uma relação especial com o Criador, seu único fim. ${ }^{42}$

Certamente, os avanços da medicina, especialmente da biologia (embriologia), trouxe, para a reflexão teológica, melhores condições para que a Igreja pudesse se fundamentar cientificamente a respeito de sua missão, em defender a vida humana já a partir da fecundação.

\section{DEFESA DA VIDA HUMANA NASCENTE}

A "Declaração sobre o aborto provocado" da Sagrada Congregação para a Doutrina da Fé do ano de 1974, durante o pontificado de Paulo VI, na

\footnotetext{
PAULO II, João. Evangelium Vitae, n. 46.

Ibidem.

1 Ibidem, p. 13.

42 Sagrada Congregação para a Doutrina da Fé. Donum Vitae, Introdução, n. 5.
} 
sua segunda parte, nos faz um apanhado histórico da trajetória da Tradição da Igreja, no concernente à doutrina sobre a defesa da vida do nascituro.

Esta respectiva Declaração começa com uma afirmação bíblica, de que Deus não fez a morte, nem se alegra com a morte dos vivos, conforme está no livro de Sabedoria 1,13, e tudo o que foi criado só tem sentido por causa da existência humana: imagem de Deus e coroamento do mundo.

A morte, que entrou no mundo por meio do pecado, será vencida definitivamente pela ressurreição em Cristo Jesus: "Assim como todos morrem em Adão, em Cristo todos receberão a vida (1Cor 15,22)".

Podemos constatar que, mesmo a Igreja não tendo uma posição unânime a respeito do momento em que a alma espiritual é infundida, o ensinamento moral da Igreja sempre foi constante, no que diz respeito ao aborto. " $A$ Tradição da Igreja sempre considerou a vida humana como algo que deve ser protegido e favorecido, desde o seu início e durante as diversas fases do seu desenvolvimento". ${ }^{43}$

A denúncia cristã mais antiga sobre o aborto se encontra naquele documento catequético das comunidades cristãs primitivas, chamado Didaché: "Tu não matarás com o aborto o fruto do seio e não farás perecer a criança já nascida". ${ }^{4}$

Alguns concílios introduziram sansões canônicas contra os praticantes do aborto. Desde o século IV, são excomungados os que provocam o aborto, conforme podemos conferir nos Concílio de Elvira do ano 303, cânon 63 e no Concílio de Ancira do ano 314, cânon 21.

Atenágoras, filósofo apologista cristão grego do século II, considerava homicidas aquelas mulheres que usavam medicamentos para a prática do aborto. Tertuliano também assumiu a mesma postura, quando afirmou: "ÉE um homicídio antecipado impedir alguém de nascer; pouco importa que se arranque a alma já nascida, ou que se faça desaparecer aquela que está ainda para nascer. É já um homem aquele que o virá a ser". ${ }^{45}$

\footnotetext{
43 Sagrada Congregação para a Doutrina da Fé. Documentos publicados desde o Concílio Vaticano II até nossos dias (1965-2010). Declaração sobre o aborto provocado II, n. 6.

44 Didaché II, n. 2.

45 Sagrada Congregação para a Doutrina da Fé, op. cit. II, n. 6.
} 
O período patrístico foi marcado por opiniões diferentes sobre o momento da infusão da alma. São Gregório Nisseno, São Basílio e Tertuliano eram a favor da animação imediata, isto é, a alma e o corpo são criados simultaneamente. Ao passo que, Santo Agostinho introduziu uma distinção entre feto perfeitamente formado e feto ainda não formado perfeitamente, sendo, portanto, a favor da teoria da animação posterior. Todavia, o ensinamento doutrinário dos Pastores e Doutores não foi abalado por dúvidas quanto à ilegitimidade do aborto.

No período da Escolástica, prevalece a hipótese de Santo Tomás de Aquino que, seguindo Aristóteles, pensa que a alma racional seja criada depois que a matéria corporal esteja capacitada para recebê-la. Aristóteles chegava a calcular este tempo em 40 dias depois para os de sexo masculino e 60 dias depois para as de sexo feminino. Porém, jamais se negou que o aborto provocado, mesmo nos primeiros dias da concepção, fosse objetivamente falta grave. São Tomás dizia que o aborto é um pecado grave contrário à lei natural. Dentro deste período, é adequado mencionar o primeiro Concílio de Mogúncia, em 887-888: "se é homicida quem destruiu com aborto o que foi concebido no útero, quanto mais será impossível desculpar-se de ser homicida aquele que matou uma criancinha que tinha ao menos um dia?"46

O papa Inocêncio XI, no ano de 1679 , condenou uma série de proposições de cunho dogmáticas e morais, entre elas aquela que aceitava a hipótese da animação tardia, a saber, após o nascimento, pois "alguns canonistas laxitas, pretendiam desculpar o aborto provocado antes do momento em que certos autores fixavam a animação espiritual do novo ser". ${ }^{47}$

O Código de Direito Canônico declara claramente que, quem provoca o aborto, incorre em excomunhão latae sententiae. ${ }^{48}$

No entanto, a mulher não incorrerá na excomunhão se estiver dentro das circunstâncias de fundo psicológico e coercitivo:

Por quem só parcialmente possuía o uso da razão; por forte ímpeto de paixão, que não tenha precedido ou totalmente impedido a deliberação

46 DENZINGER; HÜNERMANN. Compêndio dos símbolos: definições e declarações de fé e moral, p. 1467.

47 Sagrada Congregação para a Doutrina da Fé. Documentos publicados desde o Concílio Vaticano II até nossos dias (1965-2010). Declaração sobre o aborto provocado II, n. 7.

48 Código de Direito Canônico, cânon 1398. 
da mente e o consentimento da vontade; contanto que a paixão não tenha sido voluntariamente exercitada ou alimentada e por alguém que foi coagido por medo grave. ${ }^{49}$

O Código de Direito Canônico manda batizar os fetos abortivos que estiverem vivos, enquanto possível. ${ }^{50}$

\section{CONCLUSÃO}

Podemos apontar quatro conclusões sobre o ensinamento da Igreja no que diz respeito à defesa da vida humana:

1. A Igreja afirma clara e unanimemente de que a vida é inviolável desde o momento da sua concepção:

A vida humana deve ser respeitada e protegida de maneira absoluta a partir do momento da concepção. Desde o primeiro momento de sua existência, o ser humano deve ser reconhecido nos seus direitos de pessoa, entre os quais o direito inviolável de todo ser inocente à vida. ${ }^{51}$

2. A afirmação deste direito à vida do concepto tem a sua fundamentação numa reflexão sobre os dados científicos acerca do valor humano do novo ser: seu caráter biológico humano, a continuidade do processo de desenvolvimento embrionário, é um ser chamado à vida, em um contexto humano:

Desde a fecundação tem início a aventura de uma vida humana, cujas grandes capacidades exigem, cada uma, tempo para organizar-se e para encontrar-se prontas a agir. Esta doutrina permanece válida e, além disso, é confirmada, se isso fosse necessária, pelas recentes aquisições da biologia humana, que reconhece que no zigoto derivante da fecundação já está constituída a identidade biológica de um novo indivíduo humano..$^{52}$

49 Ibidem, cânon 1324, 1, 3 e 5.

50 Ibidem, cânon 871.

51 Catecismo da Igreja Católica, 2270; Donum Vitae I, n. 1.

52 Sagrada Congregação para a Doutrina da Fé. Donum Vitae I, n. 1. 
3. Partindo do pressuposto de que o embrião possui uma individualidade geneticamente distinta e diferenciada de seus pais, intrinsecamente orientada à constituição de uma pessoa humana, que origina um direito fundamental à vida, a Igreja fala sobre a recepção da alma já no momento da fecundação:

Desde o momento da concepção, a vida de todo ser humano deve ser respeitada de modo absoluto, porque o homem é, na terra, a única criatura que Deus quis por si mesma, e a alma espiritual de cada um dos homens é imediatamente criada por Deus; todo o seu ser traz a imagem do Criador. ${ }^{53}$

4. A Igreja também parte da fundamentação das Escrituras Sagradas a respeito do valor da vida humana tão defendida por Cristo, a ponto de entregar livremente a sua própria vida em favor do homem. "A vida que Deus dá ao homem [...] é, no mundo, manifestação de Deus, sinal da sua presença, vestígio da sua glória", ${ }^{54}$ conforme podemos verificar no texto bíblico:

Deus disse: "Façamos o homem à nossa imagem, como nossa semelhança, e que eles dominem sobre os peixes do mar, as aves do céu, os animais domésticos, todas as feras e todos os répteis que rastejam sobre a terra. Deus criou o homem à sua imagem, à imagem de Deus ele o criou, homem e mulher ele os criou" (Gn 1,24-27).

Para a reflexão da Igreja, o aborto constitui sempre um ato violento ao lado do infanticídio e a pessoa que o pratica voluntariamente comete uma falta grave.

Deus, com efeito, que é o Senhor da vida, confiou aos homens o nobre encargo de preservar a vida para ser exercido de maneira condigna do homem. Por isso a vida deve ser protegida com o máximo cuidado desde a concepção. $\mathrm{O}$ aborto como o infanticídio são crimes nefandos. ${ }^{55}$

A sacralidade da vida humana, que deve ser respeitada e inviolada "desde a sua concepção até a morte natural", ${ }^{6}$ não está necessária ou exclusivamente vinculada a uma perspectiva religiosa e, neste sentido, segue-se o magistério de João Paulo II:

\footnotetext{
3 Ibidem, Introdução, n. 5.

54 PAULO II, João. Evangelium Vitae, n. 34.

55 Concílio Vaticano II. Gaudium et Spes, n. 51.

56 PAULO II, João, op. cit., n. 93.
} 
O Evangelho da vida não é exclusivamente para os crentes: destina-se a todos [...]. Trata-se, com efeito, de um valor que todo ser humano pode enxergar, mesmo com a luz da razão, e, por isso, diz necessariamente respeito a todos. ${ }^{57}$

A respeito da sacralidade da vida, também pode ser abordada do ponto de vista ético: "Pode-se falar de uma sacralidade da vida sem referir-se ao contexto religioso-sacral antigo [...]. Existe uma sacralidade leiga que aparece, por exemplo, no movimento ecológico", ${ }^{8}$ como, por exemplo, o interesse superior da continuação da espécie e o respeito ao próprio corpo humano.

Numa perspectiva filosófica sobre a defesa da vida humana, podemos considerar a natureza humana, com seus finalismos intrínsecos a serem respeitados, como norma da moralidade. É própria da natureza humana a busca natural para se manter na existência individual, coletiva e se opor a qualquer força que se apresente a ela como uma ameaça. O princípio de sacralidade da vida pressupõe o caráter teleológico intrínseco ou imanente à pessoa humana, o que induz ao dever absoluto de respeitar os finalismos próprios do organismo humano, que são essencialmente os de autopreservação e reprodução. ${ }^{59}$

Neste mesmo horizonte, pode-se citar ainda a ética de Immanuel Kant, (1724-1804) em uma das fórmulas do imperativo categórico: "Atua de maneira que sempre tomes a humanidade, tanto em tua pessoa como na de qualquer outro, como fim e nunca como puro meio". ${ }^{60}$

Pode-se dizer que, da sacralidade, seja ela de uma concepção religiosa ou leiga, decorre que a vida humana é inviolável em cada momento da sua existência, inclusive na fase inicial que precede o nascimento. ${ }^{61}$

Ibidem, n. 101.

58 NEDEL, José. Ética Aplicada. Pontos e contrapontos, p. 35.

59 NEDEL, José, op. cit., p. 36-37.

60 KANT, Immanuel. Fundamentação da metafísica dos costumes. Apud. VIDAL, Marciano. Nova Moral Fundamental, p. 188.

61 PAULO II, João, op. cit., n. 61. 


\section{BIBLIOGRAFIA}

BARCHIFONTAINE, Christian De Paulo De. Bioética e início da vida: alguns desafios. São Paulo: Ideias e Letras, 2004.

A BÍBLIA DE JERUSALÉM. Edição revisada e ampliada. São Paulo: Paulus, 2002. CAMARGO, Marculino. Ética, vida e saúde. 3. ed. Petrópolis-RJ: Vozes, 1976. CATECISMO da Igreja Católica. Edição Popular. 8. ed. Petrópolis-RJ: Vozes, 1998. CIPRIANI, Giovanni. O embrião humano: na fecundação, o marco da vida. São Paulo: Paulinas, 2007.

CÓDIGO de Direito Canônico. 15. ed. São Paulo: Loyola, 2002.

COMPÊNDIO do Vaticano II. Constituições, decretos e declarações. 26. ed. Petrópolis-RJ: Vozes, 1997.

CONGREGAÇÃO para a Doutrina da Fé. Donum Vitae: Instrução sobre o respeito à vida humana nascente e a dignidade da procriação. 5. ed. São Paulo: Paulinas, 2005.

. Documentos publicados desde o Concílio Vaticano II até nossos dias (1965-2010). 1. ed. Brasília: CNBB, 2011.

COUTINHO, A. Céu. Dicionário Enciclopédico de Medicina. 3. ed. Lisboa-Portugal: Argo Editora, s. d.

DENZINGER, Heinrich; HÜNERMAN, Peter. Compêndio dos símbolos, definições e declarações de fé e moral. São Paulo: Loyola/Paulinas, 2007.

DIDACHÉ. O catecismo dos primeiros cristãos para as comunidades de hoje. 6 . ed. São Paulo: Paulus, 1989.

FERNÁNDEZ, Javier Gafo. 10 palavras-chave em Bioética. São Paulo: Paulinas, 2000.

FUENTES, Miguel Ángel. As verdades roubadas. 1. ed. em português, São Paulo: IVEPRESS, 2007.

JOSAPHAT, Carlos. Ética mundial: esperança da humanidade globalizada. Petrópolis-RJ: Vozes, 2010.

NEDEL, José. Ética aplicada: pontos e contrapontos. São Leopoldo-RS: Unisinos, 2004.

PAULO II, João. Evangelium Vitae: Carta Encíclica sobre o valor e a inviolabilidade da vida humana. 6. ed. São Paulo: Paulinas, 2009.

PONTIFÍCIO Conselho para a Família. Lexicon: termos ambíguos e discutidos sobre família, vida e questões éticas. 2. ed. Brasília: Edições CNBB, 2007.

SCHELKLE, Karl Hermann. Teologia do Novo Testamento: Éthos - comportamento moral do homem. São Paulo: Loyola, 1978. vol. 4.

SGRECCIA, Elio. Manual de Bioética. 2. ed. São Paulo: Loyola, 2002. vol. I. 
VIDAL, Marciano. Ética teológica: conceitos fundamentais. Petrópolis-RJ: Vozes, 1999.

. Moral cristã em tempos de relativismos e fundamentalismos. Aparecida: Santuário-SP, 2007.

Nova moral fundamental: o lar teológico da Ética. Aparecida-SP: Santuário/Paulinas, 2003. 